\title{
EMPAT PILAR PENDIDIKAN DALAM MENCIPTAKAN MUTU PENDIDIKAN YANG BERBUDAYA
}

\author{
Oleh : \\ Ni Wayan Desi Yuliantari \\ Mahasiswa Program Studi Magister Dharma Acarya \\ Pascasarjana IHDN Denpasar
}

\begin{abstract}
The problems of education in Indonesia is quite compleks and greatly affect learning outcomes and outputs produced a school. problems of education in Indonesia was impressed throwing responsibility. As if the government is guilty, guilty schools and so on. Advancing whereas education is a joint responsibility. Bring our determination together so that educational goals can be achieved through a process of cooperation and good communication between the family, pemeritah, school and community as the four pillars that support the implementation of education in Indonesia to deliver qualified individuals and competitiveness, as well as the four pillars of education has a role which is very important in improving the quality of education in Indonesia that can make climate or condition of an educational institution that is more secure. Education Quality cultured based curriculum in 2013 through the religious aspects, social aspects, aspects of knowledge and skills aspects, so as to realize the man who is faithful and devoted to God Almighty, noble, healthy, berilmum, capable, creative, independent, and become citizens democratic, and accountable.
\end{abstract}

Key words : education, quality, and culture

\section{PENDAHULUAN}

Pendidikan memiliki peran penting dalam memajukan suatu bangsa. Sehingga tidak heran jika pemerintah menggelontorkan pendanaan hingga triliun rupiah untuk menyelenggarakan pendidikan di Indonesia. Seiring terlaksananya proses pendidikan di Indonesia diiringi pula dengan masalah-masalah pendidikan di Indonesia. Masalah-masalah tersebut cukup compleks dan sangat mempengaruhi hasil belajar dan output yang dihasilkan suatu sekolah. Dalam menanggapi suatu masalah pendidikan di Indonesia terkesan saling melempar tanggung jawab. Seolah-olah pemerintah yang bersalah, sekolah yang bersalah dan sebagainya. Pada dasarnya untuk memajukan pendidikan di Indonesia sangat dibutuhkan dorongan semua pihak dan menjadi tanggung jawab bersama sehingga tujuan pendidikan dapat tercapai melalui proses kerjasama dan komunikasi yang baik antar keluarga, pemeritah, sekolah dan masyarakat sehngga Empat pilar yang mendukung pelaksanaan pendidikan di Indonesia dapat melahirkan individu yang berkualitas dan memiliki daya saing. Proses kerjasama tersebut penting agar proses pelaksanaan pendidikan dapat berjalan lancar dan output yang dihasilkan juga berkualitas dan tanggap terhadap perubahan zaman serta mampu 
bersaing dalam sebuah kompetisi baik dalam dunia kerja maupun bersaing dalam ilmu pengetahuan dan teknologi. sehingga peran keluarga, sekolah, masyarakat dan pemerintah memiliki arti penting dalam memajukan pendidikan di Indonesia.

Pendidikan dalam keluarga adalah tempat pertama individu lahir dan pertama kali mengenal lingkungan. Disana anak akan mengenal orang tua sebagai pendidik dan contoh dalam bertingkah laku dan mengenalkan pengetahuan dasar tentang agama, etika, bakat dan sebagainya. Di dalam lingkungan keluarga pula anak didik akan mulai mencontoh prilaku orang tuanya sebab orang tua dalam keluarga adalah sebagai media pendidikan informal yang berfungsi sebagai contoh atau tauladan terhadap anak-anaknya dirumah. Keluarga yang rukun dan harmonis akan membuat anak merasa nyaman sehingga anak akan dapat berpikir secara sehat dan berbuat secara sehat pula. Selain sebagai media pendidikan informal dan guru dirumah peran orang tua juga sebagai pengawas. Orang tua sebagai pengawas adalah orang tua melihat dan mengamati setiap prilaku anak dirumah yang dirasa menyimpang serta memberikan bimbingan untuk mengingatkan agar tidak melakukan perbuatan yang menyimpang tersebut karena tidak sesuai dengan ajaran agama dan moralitas.

Sekolah adalah lembaga formal. Dilingkungan sekolah anak didik akan mulai mengenal guru, kepala sekolah, teman sekolahnya sebagai keluarga. Sekolah merupakan tempat bagi siswa untuk belajar sesuai dengan tuntunan kurikulum yang didalamnya nanti anak didik akan mengenal berbagai ilmu yang diberikan oleh guru di sekolah. Interaksi yang terjadi selama proses belajar tersebut dipengaruhi oleh lingkungannya, yang antara lain terdiri dari atas murid, guru, petugas perpustakaan, kepala sekolah, bahan atau materi pelajaran (buku, modul, selebaran, majalah, rekaman video atau dan yang sejenisnya), dan berbagai sumber belajar dan fasilitas (proyektor, overhead, perekam pita audio dan video, radio, televisi, komputer, perpustkaan, laboratorium, pusat sumber belajar dan lain-lain (Arzad, 2013:1). Oleh karena itu, keberadaan sekolah dengan berbagai fasilitasnya sangat penting untuk menciptakan suasana belajar yang kondusif, efektif, dan efesien untuk mencapai tujuan dalam proses pembelajaran.

Masyarakat adalah lembaga non formal yang berfungsi sebagai wadah yang sangat luas untuk bersosialisasi antar warga masyarakat. Lingkungan sangat berpengaruh terhadap mental dan intelektual peserta didik. Lingkungan masyarakat menjadikan anak belajar untuk bersosialisasi dalam berbagai aktivitas seperti keagamaan, sosial dan aktivitas kesehatan lainnya di samping itu Lingkungan masyarakat memberikan wadah yang sangat luas bagi anak didik untuk belajar dan bersosialisasi serta dapat mempengaruhi anak didik. Lingkungan anak didik yang positif akan berdampak baik bagi anak didik dan lingkungan yang negatif berdampak buruk bagi anak didik, bila tidak diberikan bimbingan maka akan semakin buruk.

Pemerintah memiliki peranan strategis dalam memecahkan masalah pendidikan di Indonesia. UUD 1945 Bab XIII tentang Pendidikan dan Kebudayaan Pasal 31 ayat 1 sampai 5 yang berbunyi sebagai berikut:

1. Setiap warga negara berhak mendapat pendidikan.

2. Setiap warga negara wajib mengikuti pendidikan dasar dan pemerintah wajib membiayainya.

3. Pemerintah mengusahakan dan menyelenggarakan satu sistem pendidikan nasional, yang meningkatkan keimanan dan ketakwaan serta ahlak mulia dalam rangka mencerdaskan kehidupan bangsa yang diatur dengan Undang-undang.

4. Negara memprioritaskan anggaran pendidikan sekurang-kurangnya dua 
puluh persen dari anggaran pendapatan dan belanja negara serta dari anggaran pendapatan dan belanja daerah untuk memenuhi kebutuhan penyelenggaraan pendidikan nasional.

5. Pemerintah memajukan ilmu pengetahuan dan teknologi dengan menjunjun tinggi nilai-nilai agama dan persatuan bangsa untuk kemajuan peradaban serta kesehteraan umat manusia.

Sehingga dengan demikian pendidikan di Indonesia sudah cukup jelas diatur oleh konsititusi untuk menyelenggarakan pendidikan di indonesia sebagai upaya untuk mencerdaskan kehidupan bangsa sesuai citacita bangsa Indonesia yang terdapat pada pembukaan UUD 1945 dan Pancasila sebagai ideologi bangsa Indonesia. Namun kenyataan dilapangan tidak semua lembaga formal yakni sekolah, tidak dapat untuk menyelenggarakan pendidikan, meskipun dua puluh persen dari APBN dan APBD yang dimiliki oleh negara dan daerah untuk membiayai pelaksanaan pendidikan di Indonesia. Memajukan pendidikan di Indonesiahubungan dalam bentuk komunikasi antara keluarga, sekolah, masyarakat dan pemerintah penting untuk terus dilakukan agar tanggung jawab untuk memajukan pendidikan di Indonesia menjadi sebuah tanggung jawab bersama dan keberhasilan bersama pula sebab peran serta semua komponen dalam menyelenggarakan pendidikan sangat penting tanpa adanya dukungan makakeberhasilan proses pendidikan di Indonesia sulit untuk tercapai.

\section{PEMBAHASAN}

2.1 Pengertian Empat Pilar Pendidikan dalam kaitan dengan mutu Pendidikan yang Berbudaya

Empat pilar pendidikan memiliki peranan yang sangat penting dalam meningkatan mutu pendidikan di Indonesia yang dapat menjadikan Iklim atau keadaan suatu lembaga pendidikan yang lebih terjamin. Sanjaya (2011) dalam bukunya berjudul "Filsafat Pendidikan Agama Hindu”. Empat pilar pendidikan terdiri atas: Pendidikan keluarga (Informal), Pendidikan Sekolah (formal), Pendidikan Masyarakat (non formal) dan Pemerintah. Keempat komponen penting dalam pendidikan tersebut saling bersinegitas antara pendidikan keluarga, sekolah, masyarakat dan pemerintah yang mempengaruhi hasil belajar, sikap, etika dan prilaku peserta didik di sekolah. Tirtarahadja dan La sulo (2005) menyatakan bahwa keadaan atau iklim sosial adalah faktorfaktor lain dalam keluarga yang ikut mempengaruhi tumbuh kembang anak didik, seperti kebudayaan, tingkat kemakmuran, keadaan perumahannya, dan sebagainya. Dengan kata lain, tumbuh kembang anak dipengaruhi oleh seluruh situasi dan kondisi keluarga yang juga berefek pada out put atau kwalitas pendidikan yang dihasilkan.

Disamping itu banyak faktor yang juga berpengaruh dalam meningkatkan mutu pendidikan di Indonesia. Menurut Djamarah dan Zain (2006) mengatakan bahwa organisasi kelas juga dapat mempengaruhi dan berfungsi sebagai dasar terciptanya interaksi guru dan siswa, tetapi juga menambah terciptanya efektivitas, yaitu interaksi yang bersifat kelompok untuk membuat iklim kelas yang sehat dan efektif, selain itu budaya yang juga sangat besar memberikan pengaruh dalam keberhasilan dan kwalitas dari peserta didik. Dalam kamus Besar Bahasa Indonesia dinyatakaan bahwa budaya (kultural) merupakan pikiran, adat istiadat, sesuatu yang sudah berkembang, sesuatu yang menjadi kebiasaan yang sukar diubah. Dalam pemakaian sehari-hari orang biasanya mensinonimkan pengertian budaya dengan tradisi. Dalam hal ini, tradisi diartikan sebagai ide-ide umum, sikap dan kebiasaan dari masyarakat yang nampak dari prilaku sehari-hari yang menjadi kebiasaan dari kelompok dalam masyarakat tersebut. Dalam lembaga pendidikan misalnya, budaya 
ini berupa saling menyapa, saling menghargai, toleransi, dan lain sebagainya. Kedua, norma prilaku yaitu cara berprilaku yang sudah lazim digunakan dalam sebuah organisasi yang bertahan lama karena semua anggotanya mewariskan prilaku tersebut kepada anggota baru. Dalam lembaga pendidikan, prilaku tersebut berupa semangat untuk selalu giat belajar, selalu menjaga kebersihan, bertutur sapa santun dan berbagai prilaku mulia dan lain sebagainya. Mutu pendidikan yang berbudaya dua perspektif kontemporer berguna untuk memeriksa karakter khas sekolah, karena mereka sebagian bersaing, sebagian saling melengkapi. Budaya organisasi ini terwujud dalam norma-norma, nilai-nilai bersama, dan asumsi dasar, masing-masing terjadi pada tingkatan yang berbeda abstraksi. Sekolah memiliki budaya khas yang holistik, penuh kepercayaan, dan kontrol. Budaya dan kepercayaan dapat mempromosikan prestasi siswa, dan juga budaya kontrol humanistik akan ikut mendukung pengembangan sosioemosional siswa. Iklim organisasi merupakan kualitas sekolah yang terwujud dalam persepsi kolektif guru menuju prilaku organisasi. Mutu pendidikan dapat ditinjau dari dua titik pandang; yaitu keterbukaan prilaku dan sehatnya hubungan interpersonal baik output yang berdaya guna dan berhasil guna.

\subsection{Peran empat pilar pendidikan dalam mencip-takan Mutu Pendidikan yang berbudaya}

Telah diuraikan diatas bahwa empat pilar pendidikan terdiri atas Pendidikan keluarga (Informal), Pendidikan Sekolah (formal), Pendidikan Masyarakat (non formal) dan Pemerintah. Adapun peranan masingmasingnya sebagai berikut:

\subsubsection{Pendidikan keluarga (Informal).}

Keluarga sebagai lingkungan pendidikan yang pertama sangat penting dalam membentuk pola kepribadian anak karena dalam keluarga anak pertama kali berkenalan dengan nilai dan norma. Pendidikan keluarga memberikan pengetahuan dan keterampilan dasar, agama, dan kepercayaan, nilai moral, norma sosial dan pandangan hidup yang diperlukan peserta didik untuk dapat berperan serta dalam keluarga dan masyarakat. Indrakusuma (1973:109) menjelaskan bahwa lingkungan keluarga adalah lingkungan pendidikan yang pertama karena dalam keluarga anak pertama-tama mendapatkan didikan dan bimbingan. Pendidikan pada lingkungan keluarga juga disebut yang terutama sebab sebagian besar kehidupan anak berada dalam keluarga, sehingga pendidikan yang paling banyak diterima oleh anak adalah dalam keluarga. Tugas utama dari keluarga bagi pendidikan anak adalah sebagai peletak dasar pendidikan akhlak, moral, etika dan pandangan hidup keagaman. Terbentuknya sifat dan tabiat anak sebagian besar diambil dari kedua orang tuanya dan juga dari anggota keluarganya yang lain.

\subsubsection{Pendidikan Sekolah (Formal)}

Sekolah sebagai lembaga pendidikan formal. Sekolah merupakan sarana yang secara sengaja dirancang untuk melaksanakan pendidikan. Semakin maju suatu masyarakat semakin penting peranan sekolah dalam mempersiapkan generasi muda sebelum masuk dalam proses pembangunan masyarakat. Oleh karena itu, sangat penting menciptakan kondisi agar siswa dapat mengembangkan potensi secara optimal. Dalam hal ini kepala sekolah memiliki peranan penting dalam menciptakan kondisi demikian. Berkenaan dengan itu, ada beberapa prinsip dasar yang diharuskan mendapat perhatian, diantranya: 1) Siswa (anak didik) harus diperlakukan sebagai subjek dan bukan objek, siswa harus didorong untuk berperan serta dalam setiap perencanaan dan pengambilan keputusan yang terkait dengan kegiatan mereka. 2) Keadaan dan kondisi siswa sangat beragam ditinjau dari kondisi fisik, intelektual, sosial ekonomi, minat, bakat, dan 
sebagainya. Oleh karena itu, diperlukan wahana kegiatan yang beragam sehingga setiap siswa memiliki wahana untuk berkembang secara optimal, 3) Pada dasarnya siswa hanya termotivasi belajar, jika mereka menyenangi apa yang diajarkan, oleh karena itu mewujudkan proses pembelajaran yang menyenangkan sangat dibutuhkan. 4) Pengembangan potensi siswa tidak hanya menyangkut ranah kognitif, tetapi juga ranah afektif dan ranah psikomotor. Dengan demikian segala bentuk kegiatan pendidikan harus bersifat menyeluruh tidak hanya mengembangkan salah satu aspek saja (Sanjaya, 2011:71). Sekolah sebagai lembaga formal hendaknya harus dikelola dengan baik agar proses interaksi, komunikasi, dan proses belajar berjalan secara lancar tanpa hambatan. Meskipun dalam pelaksanaannya selalu mengalami hambatan, dengan adanya pengelolaan yang baik maka segala kendala dapat diminimalisir dan menghasilkan pendidikan yang berkwalitas dan bermutu seta berbudaya.

\subsubsection{Pendidikan Masyarakat (Non Formal)}

Kegiatan pendidikan selalu berlangsung dalam suatu lingkungan. Dalam konteks pendidikan lingkungan dapat diartikan sebagai segala sesuatu yang berada di luar diri anak didik. Lingkungan dapat berupa hal-hal yang nyata seperti orang, keadaan, politik, sosialekonomi, binatang, kebudayaan, kepercayaan, dan upaya lain yang dilakukan manusia termasuk didalamnya pendidikan. Purwanto dalam Sanjaya (2011) menjelaskan, ditinjau dari pandangan filosofisnya hubungan sekolah dengan masyarakat dapat dilihat dari kenyataan bahwa: a) Sekolah adalah bagian yang integral dari masyarakat, bukan merupakan lembaga yang terpisah dari masyarakat. b) Hak hidup dan kelangsungan sekolah bergantung pada masyarakat.c) Sekolah adalah lembaga sosial yang berfungsi untuk melayani anggota anggota masyarakat dalam bidang pendidikan. d) Kemajuan sekolah dan kemajuan masyarakat saling berkorelasi, keduanya saling membutuhkan. pendidikan dalam masyarakat memiliki peranan penting sebagai upaya untuk memperkenalkan individu kepada masyarakat yang luas, mengajarkan hubungan dan menyesuaikan diri dengan lingkungannya sehingga dapat tercipta individu yang memiliki sifat sosial.e) Sekolah adalah milik masyarakat, sekolah ada karena masyarakat memerlukannya.

\subsubsection{Pemerintah}

Pendidikan memiliki arti penting bagi manusia. Pendidikan adalah suatu usaha membawa manusia menuju kehidupan yang lebih baik. Manusia mesti memperoleh pendidikan sudah tentu ada latar belakang yang mendasari hal tersebut, yang berasal dari manusia itu sendiri. Menurut UUD 1945 Bab XIII tentang Pendidikan dan Kebudayaan Pasal 31 ayat 3 sampai 5 yang berbunyi sebagai berikut:

1. Pemerintah mengusahakan dan menye-lenggarakan satu sistem pendidikan nasional, yang meningkatkan keimanan dan ketakwaan serta ahlak mulia dalam rangka mencerdaskan kehidupan bangsa yang diatur dengan Undangundang.

2. Negara memprioritaskan anggaran pendidikan sekurang-kurangnya dua puluh persen dari anggaran pendapatan dan belanja negara serta dari anggaran pendapatan dan belanja daerah untuk memenuhi kebutuhan penyelenggaraan pendidikan nasional.

3. Pemerintah memajukan ilmu pengetahuan dan teknologi dengan menjunjun tinggi nilai-nilai agama dan persatuan bangsa untuk kemajuan peradaban serta kesehteraan umat manusia.

Dari bunyi undang-undang diatas sudah jelas bagaimana peran pemerintah dalam 
memajukan pendidikan di indonesia melalui penyelenggaraan pendidikan secara nasional dengan tujuan untuk meningkatkan keimanan dan ketaqwaan kepada Tuhan untuk mencerdaskan kehidupan bangsa dengan pendanaan melalui APBN dan APBD sekurang-kurangnya $20 \%$. Pemerintah pula memajukan ilmu pengetahuan dan teknologi dengan menjunjung tinggi nilai-nilai agama dan persatuan bangsa untuk kemajuan peradaban serta kesejahteraan manusia khususnya manusia indonesia agar dapat bersaing dengan bangsa-bangsa yang ada dibelahan dunia dengan menunjukkan hasil karya sendiri yang tidak kalah dengan bangsa-bangsa lain. Lahirnya kebijakan baru dari pemerintah pusat itu merupakan hasil diskusi oleh para Dewan Perwakilan Rakyat yang ada disenayan. Kebijakan baru atau kurikulum baru tersebut cukup membuat para pendidik harus menyesuaikan dengan kebijakan tersebut. Kurikulum 2013 merupakan sebuah kurikulum baru dalam dunia pendidikan yang ada di indonesia yang mana kompotensi inti yang ditekankan dalam kurikulum ini adalah aspek religius, aspek sosial, aspek pengetahuan dan keterampilan.

\subsection{Mutu Pendidikan berbudaya berdasarkan kurikulum 2013}

Guna melahirkan generasi yang bermutu, berkwalitas, dan berbudaya maka generasi Muda harus ikut serta dalam membagun bangsa indonesia melalui ilmu pengetahuan dan teknologi yang berlandaskan pada nilai-nilai agama yang berguna bagi dirinya, masyarakat dan peradaban manusia. Selain keempat pilar tersebut di atas yang saling mendukung dan mempengaruhi makakompotensi inti kurikulum 2013 juga andil membantu dalam meningkatkan Mutu Pendidikan yang berbudaya,. Ini dikarenakan dalam kurikulum 2013 terdapat berbagai aspek yang mendukung mutu pendidikan berbudaya yang harus dimiliki oleh Bangsa Indonesia diantaranya :

\subsubsection{Religius.}

Berbicara tentang religius erat hubungannya dengan kepercayaan umat manusia kepada Sang Maha Pencipta. Tujuan dari kehidupan agama Hindu adalah untuk membuat seseorang itu menjadi individu yang lebih baik sehinggaia dapat hidup dengan penuh keselarasan dalam dunia ini dan mencari penyatuan dengan Tuhan. Guna mewujudkan kehidupan umat yang selaras tersebut, maka setiap individu atau umat harus memiliki atau memperoleh pendidikan yang terkait dengan agama, sehingga ia bisa tahu dan paham apa yang mesti dilakukannya dalam kehidupan ini sesuai dengan ajaran serta nilai yang terdapat dalam agama anak didik masing-masing. Melalui pendidikan agama yang diberikan oleh sekolah dapat berfungsi pengemban, yaitu meningkatkan keimanan dan ketaqwaan siswa kepada Ida Sang Hyang Widhi Wasa atau Tuhan Yang Maha Esa yang telah ditanamkan di lingkungan keluarga, dan menyalurkan siswa yang mendalami bidang agama agar mereka dapat berkembang secara optimal. Fungsi ketiga, adalah perbaikan yaitu untuk memperbaiki kesalahan-kesalahan dan kelemahan-kelemahan siswa dalam pemahaman keyakinan serta pengalaman ajaran agama Hindu dalam kehidupan sehari-hari.

\subsubsection{Sosial.}

Pada dasarnya setiap sekolah mendidik anak agar menjadi anggota masyarakat yang berguna. Proses bimbingan individu ke dalam dunia sosial disebut sosialisasi. Sosialisasi dilakukan dengan mendidik indivdu tentang kebudayaan yang harus dimiliki dan dikutinya, agar ia menjadi anggota yang baik dalam masyarakat dan dalam berbagai kelompok khusus. Sosialisasi dapat dianggap sama dengan pendidikan. Dengan tak sadar ia belajar dengan mendapatkan informasi secarainsidental dalam berbagai situasi sambil mengamati kelakuan orang lain, membaca buku, menonton tv, mendengar percakapan orang dan 
sebagainya atau menyerap kebiasaankebiasaan dalam lingkungannya. Seluruh proses sosialisasi berlangsung dalam interaksi individu dengan lingkungannya (Nasution, 2011:126). Lingkungan sosial sekolah dibedakan atas lingkungan sekolah yang seagama (homogen) dan lingkungan sekolah berbeda agama (heterogen) begitu pula dengan suku-suku menjadi warna disuatu sekolah dan sebagainya. Oleh karena itu perlu diciptakan suasana atau hubungan yang harmonis dengan suasana yang demikian. Misalnya saling hormat-menghormati, saling menghargai, saling memiliki dan menjaga nama baik sekolah baik didalam sekolah maupun diluar sekolah.

\subsubsection{Berpengetahuan.}

Pengetahuan dapat diproleh oleh anak didik melalui belajar. Belajar itu bisa dari melihat, bimbingan, pelatihan dan juga pengalaman. Pengetahuan yang dimiliki oleh peserta didik dapat mengatasi segala kesulitan yang dialaminya. Pengetahuan yang dimiliki oleh anak didik hendaknya harus diimbangi dengan kecerdasan spritual ( $S Q$ ) dan kecerdasan emosional (EQ). Kecerdasan emosional dan spritual merupakan satu komponen yang sangat penting dalam menjalani kehidupan. Kecerdasan intelektual semata tidak akan cukup. Seseorang yang cerdas tanpa spritualitas dan emosi yang cerdas hanya akan melahirkan komputer dan robot jenius pemusnah massa; ambil saja contoh Amrozi cs. Mereka sungguh cerdas mampu membuat bom dengan daya ledak, namun mereka tidak dapat memanfaatkannya untuk kebaikan, akhirnya bom itu hanya menjadi mesin pembunuh. Lihat saja catatan sejarah, meledaknya bom hirosimha merupakan kejeniusan yang mematikan. Meledaknya bom fosfor di jalur Gaza juga bukti nyata betapa kecerdasan mental saja, tanpa kecerdasan spritual dan emosional adalah pembawa kehancuran. Jika dilihat lebih lanjut kerusakan yang diciptakan karena kurangnya kecerdasan spritual dan emosional (Yudiantara, 2009 : 6). Sehingga keberadaan sekolah sebagai wadah tempat untuk belajar dan menuntut ilmu pengetahuan dapat memberikan dampak positif dan negatif. Yang terpenting dapat menggunakan pengetahuan tersebut dimbangi dengan kecerdasan spritual dan emosional.

\subsubsection{Terampil.}

Sekolah tempat mengembangkan keterampilan dan melatih diri. Keterampilan yang dimiliki oleh peserta didik dapat menjamin kehidupannya nanti selain itu dapat membanggakan nama sekolah melalui kompetisi atau pameran misalnya anak didik yang memiliki keterampilan dalam bidang seni lukis, seni patung, seni suara dan sebagainya patut diberikan dukungan melalui pemahaman teori dan praktek disekolah. Ketika anak didik telah keluar dari sekolah dengan menyandang ijazah dapat membuat lapangan pekerjaan atau dapat diterima oleh sebuah perusahaan yang sesuai dengan kemapuannya atau hasil pendidikannya disekolah. Selain itu, dengan bersekolah setidaknya seorang anak dapat membaca, menulis, dan berhitung yang diperlukan dalam tiap masyarakat modern. Selain itu diproleh sejumlah pengetahuan lain seperti sejarah, geografi, kesehatan, kewarganegaraan, fisika, biologi, bahasa, seni dan lain sebagainya yang membekali anak untuk melanjutkan pelajarannya atau memperluas pandangan dan pemahaman tentang masalahmasalah dunia (Nasution, 2011 : 16).

Dengan demikian untuk menciptakan mutu yang berbudaya bila merujuk pada kompotensi inti kurikulum 2013 yakni anak didik hendaknya religius guna meningkatkan ketaqwaan kepada Tuhan yang Maha Esa dengan melaksanakan ajarannya serta menjauhi larangannya. Aspek sosial sebagai wadah untuk melatih interaksi antar warga sekolahnya dengan ramah, sopan santun dan saling menghormati satu sama lain. Aspek pengetahuan bahwa sekolah tempat untuk belajar untuk mendapatkan ilmu 
pengetahuan, ilmu pengetahuan tersebut akan lebih baik jika diimbangi dengan kecerdasan spritual dan emosional dan terampil sebagai upaya untuk mengembangkan minat dan bakatnya yang berguna bagi dirinya dikemudian hari. Secara nasional agar tercapai tujuan pendidikan nasional yakni dalam UU Sisdiknas No. 20 Tahun 2003 tersebut, dikatakan: "Pendidikan nasional bertujuan untuk berkembangnya potensi peserta didik agar menjadi manusia yang beriman dan bertaqwa kepada Tuhan yang Maha Esa, berakhlak mulia, sehat, berilmum, cakap, kreatif, mandiri, dan menjadi warga negara yang demokratis, serta bertanggung jawab".

\section{KESIMPULAN}

Empat pilar pendidikan yakni Pendidikan keluarga (formal), Pendidikan sekolah (Non Formal) Pendidikan masyarakat (informal) dan Pemerintah. Mutu pendidikan dapat terwujud apabila situasi dan kondisi hubungan sekolah dan warga sekolah dalam proses interaksi dan proses belajar mengajar dapat menciptakan suasana yang kondusif, efektif dan efesian sebagai upaya untuk mencapai tujuan pengajaran serta menciptakan mutu pendidikan yang berbudaya dengan memenuhi segala komponen-komponen belajar seperti fasilitas ruang belajar dengan segala fasilitasnya untuk membentuk pribadi anak didik yang religus, sosial, berpengetahuan dan terampil. Peran empat pilar pendidikan dalam menciptakan mutu pendidikan berbudaya saling mendukung dan mempengaruhi untuk melahirkan generasi muda yang yang cerdas dan bersama-sama membangun bangsa indonesia. Realisasinya adalah hubungan yang harmonis di dalam keluarga anak didik dan peran serta orang tua, pihak sekolah, masyarakat, dan pemerintah menanamkan nilai-nilai dasar agama, moral dan sikap sangat memberikan jaminan penyelengaaraan pendidikan demi mencerdaskan kehidupan bangsa melalui ilmu pengetahuan dan teknologi yang berlandaskan pada nilai-nilai agama agar berguna bagi dirinya, masyarakat dan peradaban manusia. Mutu pendidikan yang berbudaya yakni religius, sosial, berpengetahaun dan terampil. Dengan memenuhi kompotensi inti merupakan tujuan dari berdirinya suatu sekolah untuk melahirkan output yang berdaya saing dan berbudaya serta tercapainya tujuan pendidikan nasional.

\section{DAFTAR PUSTAKA}

Djamarah, Syaiful dan Zain, Aswan. 2006. Strategi Belajar Mengajar. Rineka Cipta: Jakarta

Hadari Nawawi. 1989. Organisasi Sekolah dan Pengelolaan Kelas. Jakarta. Cet.III. Masagung

Indrakusuma, Amier Daien. 1973. Pengantar Ilmu Pendidikan. Jogjakarta

Ibrahim R. dan Nana. S,. 1993. Penelitian dan Penelilaian Pendidikan. Bandung: Sinar Baru Algesindo

Nasution. 2011. Sosiologi Pendidikan. Jakarta. Bumi Aksara

Oemar Hamalik. 1991. Pendekatan Baru Strategi Belajar-Mengajar Berdasarkan CBSA. Sinar Baru. Bandung.

Roestiyah. 1998. Starategi Belajar Mengajar. Rineka Cipta. Jakarta

Rusman, 2010. Model-Model Pembelajaran Mengembangkan Profesionalisme Guru. PT Raja Grafindo Persada. Jakarta

Sudjana, Nana. 1989. Dasar-dasar Proses Belajar Mengajar. CV Sinar Baru. Bandung

Sardiman. 2006. Interaksi \& Motivasi Belajar Menagajar. Jakarta : PT RajaGrafindo Persada 
Seneng, I Ketut dan Indiani, Ni Made. 2008. Strategi Pembelajaran. Direktorat Jenderal Bimbingan Masyarakat Hindu Departemenn agama RI. 2008. Jakarta

Sutikno, sobry. 2014. Manajemen Pendidikan. Holistica: Surabaya

Sanjaya, Putu. 2011. Filsafat Pendidikan Agama Hindu.Surabaya. Paramita

Suharsimi Arikunto. 1988. Pengelolaan Kelas dan Siswa Sebuah Pendekatan Evaluatif. Cet. II. Rajawali Pers Jakarta.

Sudirman N, dkk. 1991. Ilmu Pendidikan. Remaja Rosdakarya: Bandung.
Tilaar, H.A.R. 2002. Manajemen Pendidikan Nasional. Bandung. PT Remaja Rosdakarya

Umar, Tirtarahardja dan Sulo, S. L. La. 2005. Pengantar Pendidikan. Rineka Cipta: Jakarta

Undang-Undang Dasar Negara Indonesia Tahun 1945

Undang-undang RI tentang Sisdiknas No. 20 Tahun 2003

Yudiantara, I Putu. 2009. Mendayagunakan $E Q$ dan $S Q$ melalui Psikologi-Hindu. Surabaya: Paramita 